\title{
Carbon emissions from selective logging in the southern Yucatan Peninsula, Mexico
}

\section{Emisiones de carbono del aprovechamiento forestal selectivo en el sur de la Península de Yucatán, México}

\author{
Samaria Armenta-Montero', Edward A. Ellis ${ }^{*}$, Peter W. Ellis ${ }^{2}$, Robert Hunter Manson ${ }^{3}$, \\ Citlalli López-Binnqüist ${ }^{1}$ and Juan Alberto Villaseñor Pérez ${ }^{4}$
}

\begin{abstract}
1 Universidad Veracruzana. Centro de investigaciones
Tropicales. Xalapa, Veracruz, México 1

3 Instituto de Ecología, A.C. Xalapa, Veracruz, Mexico.

2 The Nature Conservancy. Arlington, VA, USA.

4 The Nature Conservancy. Merida, Yucatan, Mexico.

* Corresponding author. ellis_eddie@ayahoo.com
\end{abstract}

\begin{abstract}
Tropical forests contain approximately $40 \%$ of the carbon accumulated in terrestrial biomass. However, the loss and degradation of forests worldwide liberates this carbon and contributes $11 \%$ of total global emissions. Forest degradation is an increasing source of carbon emissions, contributing $25 \%$ in tropical forest environments; and selective logging is among the principal causes. The central objective of this study was to evaluate biomass impacts and committed carbon emissions from selective logging in two forestry communities (ejidos with common forest use and rights) in the southern Yucatan Peninsula, Mexico. We compared emissions performance from logging operations in both ejidos, one of them certified as sustainably managed by the Forest Stewardship Council (FSC). The species of roundwood extracted as well as the number of impacted trees from harvesting were recorded and the type of collateral damage from felling, skidding, and transport of timber was quantified. Biomass of harvested timber and impacted vegetation was estimated to calculate carbon emissions using allometric equations. Results indicated that selective logging generated $1.2 \mathrm{Mg} \mathrm{m}^{-3}$ and $1.5 \mathrm{Mg} \mathrm{m}{ }^{-3}$ of total carbon emissions in the Caobas and 20 de Noviembre ejidos, with 5\% and $12 \%$ corresponding to collateral damage during felling, respectively. Overall lower committed emissions and collateral damage from felling and skidding were present in Caobas, the FSC certified ejido. We discuss how forest certification, through implementation of reduced impact logging (RIL) practices can significantly reduce carbon emissions from selective logging in the region.
\end{abstract}

KEYWORDS: carbon emissions, collateral damage, forest certification, reduced impact logging, selective logging.

\section{RESUMEN}

Los bosques tropicales contienen aproximadamente 40\% del carbono acumulado en la biomasa terrestre. Sin embargo, la pérdida y degradación de los bosques libera este carbono y contribuye con 11\% de las emisiones globales totales. La degradación forestal es una fuente creciente de emisiones de carbono, que contribuye con $25 \%$ en ambientes tropicales; y la tala selectiva es una de las principales causas. El objetivo central de este estudio fue evaluar los impactos a la biomasa y las emisiones de carbono generadas por la tala selectiva en dos comunidades forestales (ejidos con uso y derecho forestal común) en el sur de la Península de Yucatán, México. Se comparó el rendimiento de emisiones de las operaciones de tala en ambos ejidos, uno de ellos certificado con manejo sostenible por el Consejo de Administración Forestal (FSC). Se registraron las especies de madera en rollo extraídas, así como el número de árboles afectados por la cosecha, y se cuantificó el tipo de daño colateral causado por la tala, el arrastre y el transporte de madera. La biomasa de la madera cosechada y la vegetación impactada fue estimada para calcular las emisiones de carbono utilizando ecuaciones alométricas. Los resultados indicaron que la tala selectiva generó $1.2 \mathrm{Mg} \mathrm{m}^{-3}$ y $1.5 \mathrm{Mg} \mathrm{m}^{-3}$ de emisiones de carbono totales en los ejidos de Caobas y 20 de Noviembre, con $5 \%$ y $12 \%$ correspondientes a daños colaterales por derribo, respectivamente. En general, hubo menores emisiones generadas y daño colateral por derribo y arrastre en Caobas, el ejido certificado por FSC. Se discutió cómo la certificación forestal, a través de prácticas de tala de impacto reducido (RIL) pueden reducir significativamente las emisiones de carbono de la tala selectiva en la región.

PALABRAS CLAVE: certificación forestal; daños colaterales; emisiones de carbono; tala de impacto reducido; tala selectiva. 


\section{INTRODUCTION}

Climate change caused partly by anthropogenic emissions of $\mathrm{CO}_{2}$, increases global risks associated with increasing temperature (Intergovernmental Panel on Climate Change [IPCC], 2014). Terrestrial ecosystems are an important sink of $\mathrm{CO}_{2}$ (1 Gt of carbon per year) (Fahey et al., 2009), and tropical forests contain approximately $40 \%$ of the carbon accumulated in terrestrial biomass (Denman et al., 2007), $60 \%$ of which corresponds to the organic carbon in the soil (Scharlemann, Tanner, Hiederer \& Kapos, 2014). In the case of Mexico, estimates suggest that the amount of carbon stored in both tropical and temperate forests is between $4361 \mathrm{Mt}$ and $5924 \mathrm{Mt}$ (Masera, Ordoñez \& Dirzo, 1997), resulting in a significant global carbon sink.

Loss and degradation of forests are one of the most important sources of $\mathrm{CO}_{2}$ emissions (Masera et al., 1997). Global rates of forest loss are estimated to be 13 million hectares per year (ha $\mathrm{yr}^{-1}$ ) (Kindermann et al., 2008), and from 1970 to 2010 they accounted for $11 \%$ of $\mathrm{CO}_{2}$ emissions, considered one of the principal causes of climate change (IPCC, 2014). Net forest loss from 2001 to 2010 has resulted in emissions of $4.0 \mathrm{Gt} \mathrm{yr}^{-1}$ of $\mathrm{CO}_{2}$, decreasing to 2.9 $\mathrm{Gt} \mathrm{yr}^{-1}$ from 2011 to 2015, however, emissions of $\mathrm{CO}_{2}$

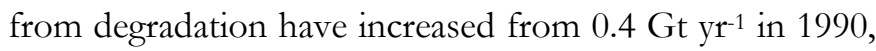
to $1.0 \mathrm{Gt} \mathrm{yr}^{-1}$ from 2011 to 2015 (Federici, Tubiello, Salvatore, Jacobs \& Schmidhuber, 2015). In tropical forest regions, degradation contributes $20 \%$ to $25 \%$ of the total forest emissions (Griscom et al., 2009; Pearson, Brown, Murray \& Sidman, 2017), 2.1 billion tons of $\mathrm{CO}_{2}$ per year (Pearson et al., 2017). During the 1990s, carbon emissions associated with land use change and forestry made up the second largest source of carbon emissions (30\%) after fossil fuel emissions (67\%) in Mexico (Instituto Nacional de Ecología y Cambio Climático [INECC], 2012). However, by 2010, forest related carbon emissions decreased from $101257 \mathrm{Mt}$ to $45670 \mathrm{Mt}$ and moved to fourth place (6.3\%) in national emissions after fossil fuels, agriculture, and industrial processes (INECC, 2012), mainly due to a decrease in deforestation in Mexico (Food and Agriculture Organization ([FAO], 2015).
While deforestation implies the removal of forest cover, forests degradation involves reductions in the capacity of forests to provide goods and environmental services through changes that affect their biomass, structure, and composition (Simula \& Mansur, 2011). The main causes of degradation are unsustainable or illegal logging, shifting agriculture, invasive species, fire, firewood collection, and grazing of livestock (Griscom et al., 2009; Halperin \& Turner, 2013; Thompson et al., 2013). Thus, degradation typically results in the maintenance of forest cover, but with subtle loses in the forests capacity to provide environmental services, such as carbon sequestration and storage (Sasaki \& Putz, 2009). Therefore, detecting and monitoring forest degradation is more difficult and costlier than deforestation since it can occur at different levels of impact or successional phases (Putz \& Redford, 2010). To facilitate quantifying and monitoring degradation, carbon-based degradation is often applied as a working definition, which is the direct, human-induced, reduction in forest carbon reserves from natural forest ecosystems that persists for a period of time, and is not classified as deforestation (Murdiyarso et al., 2008; Griscom et al., 2009).

It has been documented that selective logging contributes to carbon emissions and stock reductions (Bryan, Shearman, Ash \& Kirkpatrick, 2010; Martin, Newton, Pfeifer, Khoo \& Bullock, 2015). Selective logging is the removal of commercially valuable trees from a forest (Martin et al., 2015), usually at very low densities, depending on the scale of the operation. Selective logging in tropical forests is carried out on a large scale in countries such as Brazil, Borneo, Guyana, Indonesia, Malaysia, Papua New Guinea, Central African Republic and other tropical countries (Putz et al., 2012). Globally there are around 400 million hectares of tropical forest with timber exploitation by selective logging (Asner, Rudel, Aide, Defries \& Emerson, 2009) which contribute to many local and regional economies (Martin et al., 2015). Due to the diversity of tropical trees and limited timber markets, typically up to 20 trees per hectare are harvested, and for each tree felled, between 10 and 20 additional trees are 
estimated to be damaged (Putz et al., 2008b). Furthermore, there are direct impacts from skidding logs (the removal of logs from the forest) and construction of logging infrastructure (e.g. logging roads and log landings) (Martin et al., 2015; Putz et al., 2012). However, when undertaken with proper management plans and ensuring sustainable yields, selective logging shows potential in reducing deforestation and maintaining carbon stocks (Putz et al., 2012).

Given the importance of degradation as a source of carbon emissions, the United Nations Framework Convention on Climate Change (UNFCCC), during the Montreal and Copenhagen conferences in 2005 and 2009 respectively, establishes the importance of a mechanism for Reduction in Emissions from Deforestation and Degradation (REDD) (Angelsen et al., 2009), which would subsequently also focus on the conservation, sustainable management of forests and increased carbon stocks (REDD +) (Morales-Barquero et al., 2014). Research to evaluate and reduce carbon emissions caused by degradation through selective logging is urgently needed to facilitate the implementation of REDD+ (MoralesBarquero et al., 2014; Foundation for International Environmental Law and Development [FIELD], 2013). REDD + activities in Mexico are relatively advanced due to favorable conditions such as secure forest tenure, community forest management, existing payment for environmental services programs, and free and open access to national forest inventory data (Borrego \& Skutsch, 2014). However, in Mexico, efforts to quantitatively assess carbon emissions and reduction potentials from selective logging, in addition to determining the potential in carbon sequestration from managed forests, have been minimal.

On the Yucatan Peninsula, approximately $60 \%$ of forested land is communally owned (Instituto Nacional de Estadística y Geografía [Inegi], 2016) by 1389 ejidos. Of these, 220 or $16 \%$ ejidos are engaged in forestry activities, mainly through selective logging, with 50\% located in the state of Quintana Roo (Inegi, 2016). Community forest management in ejidos is recognized as the management of forest resources and services by communities within or near forest areas that have self-governance under shared norms, collective rights or community institutions (Cronkleton, Bray \& Medina, 2011; Ellis et al., 2015). Various studies have documented that community forest management for timber production and subsistence purposes can have positive impacts in reducing deforestation and conserving forests (Cronkleton et al., 2011; Porter-Bolland et al., 2012), although its impacts on forest degradation are mostly unknown on the Yucatan Peninsula.

A recent REDD+ strategy that targets selective logging in tropical forests is the implementation of Reduced Impact Logging (RIL) practices in order to reduce the negative impacts of timber harvesting through improved forestry practices such as directional felling, skid trail and road planning, and pre-logging liana cutting (Putz, Sist, Fredericksen \& Dykstra, 2008a). According to various studies, the impact of collateral damage to trees can be reduced by up to $50 \%$ when implementing RIL practices (Mazzei et al., 2010; West, Vidal \& Putz, 2014). Nevertheless, in Mexico, carbon emissions from selective logging have not been estimated, nor have there been evaluations of the impact of RIL practices on emissions reductions. Also lacking are evaluations of improvements achieved through forest certification. Field studies are thus urgently needed to obtain data on carbon emissions from selective logging in the country.

\section{OBJectives}

In this study, we measure carbon emissions from selective logging in two forestry ejidos on the Yucatan Peninsula, Caobas and 20 de Noviembre. Moreover, in the former case, we evaluate the impact of implementing RIL practices achieved through the Forest Stewardship Council (FSC) certification.

\section{MATERIALS AND METHODS}

\section{Study Area}

This study was conducted in a region known as the Selva Maya, specifically in the southern portion of the Yucatan Peninsula. The Caobas ejido is located in the municipality 
of Othón P. Blanco in the state of Quintana Roo and the 20 de Noviembre ejido is located in the municipality of Calakmul in Campeche state (Fig. 1). These ejidos were chosen because they are among the largest and most representative forest communities of the region. Moreover, they share similar forest management and cutting areas, forest type (sub perennial medium tropical forest) and history of community forest management since 1983 . However, as noted above, they show significant differences in management practices. Both ejidos are located at an altitude of around 190 meters above sea level (m a.s.l.) and have a predominant warm subhumid climate with abundant rains during the summer, an average annual rainfall of 1200 $\mathrm{mm}$, and average annual temperature of $26{ }^{\circ} \mathrm{C}$. The dominant soils are gray to reddish Redzinas and Gleysols, which have low permeability or drainage, a thin layer of organic matter and limestone texture (González, Schmook \& Calmé, 2007; Sociedad de Productores Forestales Ejidales de Quintana Roo S. C. [SPFEQRSC], 2012). The main economic activities for both ejidos are forest related with timber harvesting occurring from January to July and tapping chicle or gum (Manilkara zapota (L.) P. Royen) from the forest from August to January.

Both ejidos apply a polycyclic silvicultural system with a 75-year rotation and a 25-year cutting cycle based on the growth and yield of mahogany (Swietenia macropbylla King), the guiding timber species for silviculture in the region (Ellis et al., 2015; Navarro-Martínez et al., 2017). Timber harvesting must be done according to an authorized Forest
Management Plan, for a period of 10 years to 20 years depending on the size of the management area and number of annual cutting areas (ACA). Selective logging is conducted within the delimited ACAs where potential volumes are assessed based on previous forest inventories, and harvested trees are marked in the forest prior to felling. Minimum cutting diameter for precious or high value timber, such as mahogany, chicle, and Spanish cedar (Cedrela odorata L.) is $55 \mathrm{~cm}$ diameter at breast height (dbh), and $35 \mathrm{~cm}$ dbh for other common tropical species. The trees that are ultimately harvested from the ACA are a function of the particular volume demand for different timber species by buyers in the region (Ellis et al., 2019). Differences in forest management practices of both ejidos are presented in table 1. For example, skidding of logs to log landings is done for the most part using a modified agricultural tractor in Caobas, while a larger and wider conventional articulated forestry tractor (skidder) is used in 20 de Noviembre. The Caobas ejido has a forest area of 32500 ha, including a wildlife conservation area of 8797 ha, and is certified by the FSC of Rainforest Alliance, implementing RIL practices such as directional felling, skid trail planning and other conservation measures. The 20 de Noviembre ejido has a forest area of 22725 ha with a community conservation zone of 1913 ha and has been developing plans to implement RIL practices to improve forest management, but currently employing conventional logging methods.

TABLE 1. RIL practices conducted in the ejidos Caobas and 20 de Noviembre of the Yucatán peninsula, Mexico.

\begin{tabular}{lcc}
\hline \multicolumn{1}{c}{ RIL Practice } & Ejido Caobas & Ejido 2O de Noviembre \\
\hline Planning of logging roads and skid trails & YES & NO \\
Mapping and marking of harvested trees & YES & YES \\
Pre-cutting of lianas and vines & YES & NO \\
Directional felling & YES & NO \\
Cutting stumps close to ground level & NO & NO \\
Type of machinery & Agricultural tractor & Tree farmer \\
\hline
\end{tabular}




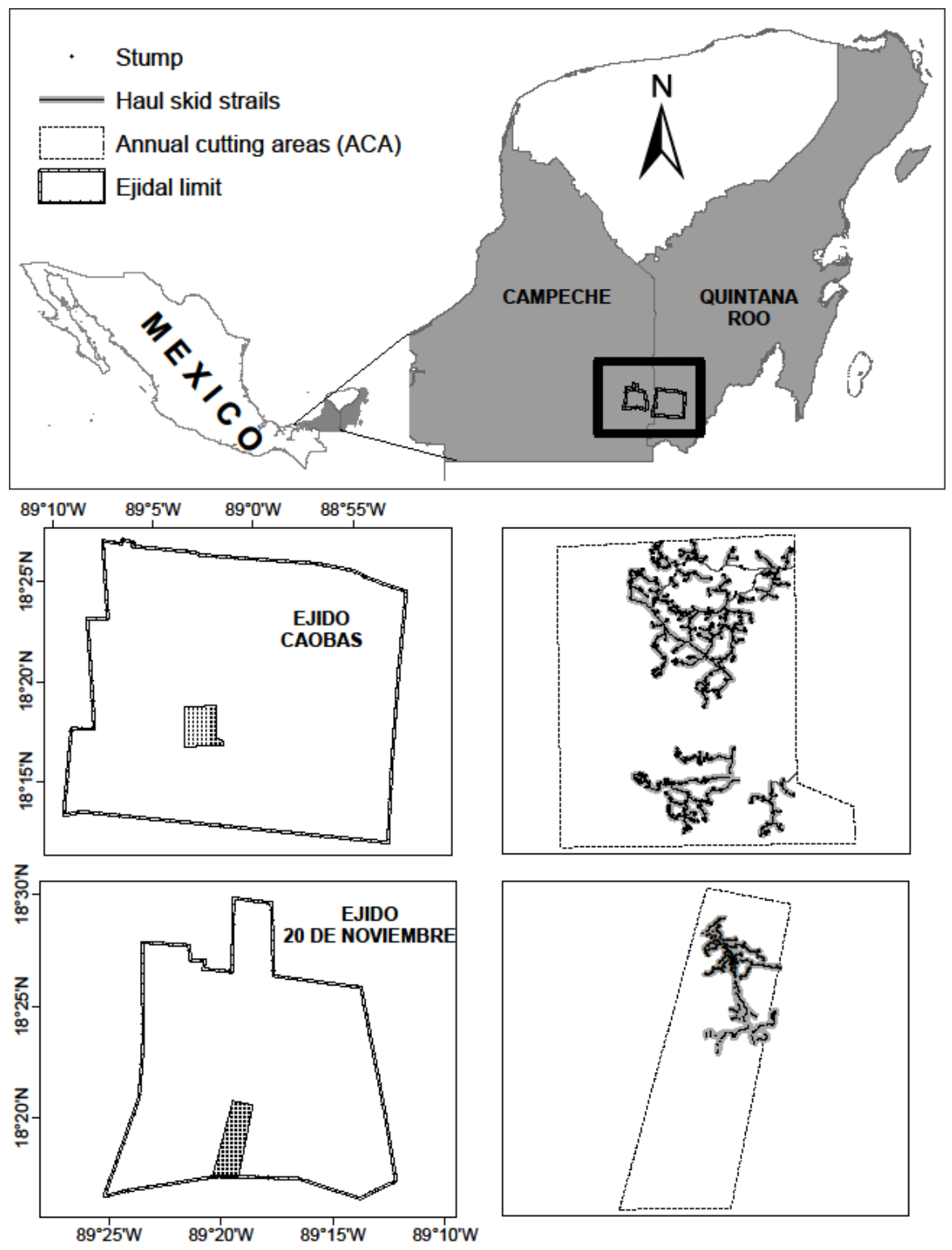

FIGURE 1. Geographic location of the ejidos Caobas and 20 de Noviembre in the southern Yucatán, Peninsula, Mexico.

\section{Field sampling}

Field measurements of harvested trees and the impacts on tree biomass from selective logging were conducted in both ejidos applying a methodology adapted from Griscom, Ellis and Putz (2014). The entire 2013 ACA (1000 ha) of the 20 de Noviembre ejido was sampled during January and April 2014. The data was collected for The Nature Conservancy by the ejido forest technician and provided by P. Ellis. Similarly, in the ejido Caobas, $85 \%$ of the 2014 ACA (1059 ha) was sampled at the time of harvest. Sampling involved measuring harvested trees and collateral damage from felling, skidding logs, and transporting timber (which includes construction of log landings and logging roads) in selectively logged forests. Biomass impacts were assessed for each activity type involved in harvesting timber (felling, skidding and transport) as described in Walker et al., (2012) and Griscom et al., (2014):

- Felling. All felling gaps in the ACA were located and georeferenced, and in all the felling gaps in the 20 de Noviembre ejido and $15 \%$ of the felling gaps in the 
Caobas ejido, the species and dimensions of the felled tree (stump diameter, remnant crown diameter and length of removed trunk) were recorded. Also, the species, type of damage and stem diameter of damaged trees and palms caused by felling were recorded.

- Skidding. The skid trails formed by skidding logs were also measured and georeferenced in the ACA. Plots (10 $\mathrm{m} \times$ the width of the trail) were established every $100 \mathrm{~m}$ along the length of skid trails, recording species, type of collateral damage and stem diameter of impacted trees and palms, while also noting the machinery used for skidding, i.e., a modified agricultural tractor $(\mathrm{Tr})$ or a Tree Farmer (Tf), and whether the skid trail was new or old.

- Transport. Access roads and log landings (locally known as "bacadillas") were georeferenced and measured. The latter correspond to zones where all of the vegetation has been cleared in an area of approximately $500 \mathrm{~m}^{2}$ to $800 \mathrm{~m}^{2}$ in order to temporarily collect all of the harvested trunks before transport. The dimensions (width and length) and shape of approximately eight log landings were measured in each ejido to calculate biomass removal. Construction of access roads also involves clearing of all vegetation, and the entire length and width of the roads at 10 different sections within the ACA were measured to calculate biomass removal. Collateral damage to above ground biomass during felling and skidding activities was recorded for all trees greater than $5 \mathrm{~cm}$ dbh (diameter at breast height) within sampled felling gaps and skid trail plots, and damage to trees was categorized as: G (totally fallen), S (snapped or broken), C (crown damage), B (bark stripped) and $\mathrm{L}$ (leaning $\geq 10^{\circ}$ ). In addition, the type of impacted tree was categorized as commercial (COT), non-commercial (NCOT), or palm (P).

The reference biomass and carbon stocks $(C)$ present in the sampled ACA prior to logging were calculated based on inventories conducted in 2005-2008 in a collaboration between ejidos and the National Forestry Commission (Conafor). This inventory consisted of a network of successive circular plots of $500 \mathrm{~m}^{2}$, located along the length of imaginary parallel lines within the permanent forest management area. These sampling lines had a lateral equidistance of $250 \mathrm{~m}$. Identification of trees, dbh, and height were measured in each plot. In order to calculate the biomass and carbon reserves present before logging, we considered the plots established within the ACA of both ejidos prior to felling.

We use forest biomass calculations to evaluate impacts from clearing for access road and log landing construction during the transport of timber. The aim of the field sampling methodology was to compare the impacts on biomass and carbon emissions from the different forestry activities (felling, skidding and transport) by the use allometric equations, and to identify those that contribute the greatest quantity of carbon during selective logging harvesting operations.

Although there are effects on carbon in organic soil (Pinard, Putz \& Tay, 2000; Abdullahi, Siwar, Shaharudin \& Anizan, 2018), we do not include this part because it is considered that selective logging has a low impact on the short-term carbon stock (Vanguelova, Pitman, Luiro \& Helmisaari, 2010; Zhang et al., 2018).

\section{Data analysis}

Data collected during field sampling was used to estimate the impacted aboveground biomass and calculate carbon emissions from selectively logged areas. To estimate biomass, we considered five allometric equations used for calculating above ground biomass (AGB) of tropical dry forests (Table 2); three generated for the Yucatán Peninsula (Cairns, Olmsted, Granados \& Argaez, 2003; UrquizaHaas, Dolman \& Peres, 2007; Guyot \& Proust, unpublished data) and two global equations (Chave et al., 2005; Chave et al., 2014). Since these allometric equations integrate tree height data, the required total height data was estimated using the formula of Chave et al. (2014): $\mathrm{H}=$ $\exp (0.893-0.385741+0.760 * \operatorname{In}(\mathrm{D})-0.0340 * \operatorname{In}(\mathrm{D}) 2)$. For wood density per species, the records of Gil-González and Prada-Garzón (2008) and the International Tropical Timber Organization (ITTO, 2012) were used, as well as the project page of Reinforcing REDD+ and South-South Cooperation (Conafor, 2015). 
TABLE 2. Allometric equations used to obtain biomass in tropical dry forests.

\begin{tabular}{lll}
\hline Author & $R^{2}$ & Allometric equation \\
\hline Cairns et al., 2003 & 0.956 & $\mathrm{AGB}=\exp \left[-2.173+0.868^{*} \ln \left(\mathrm{D}^{2} \mathrm{H}\right)+0.0939 / 2\right]$ \\
Chave et al., 2014 & 0.932 & $\mathrm{AGB}=0.0673\left(\mathrm{pD}^{2} \mathrm{H}\right)^{0.976}$ \\
Chave et al., 2005 (Model I) & 0.923 & $\mathrm{AGB}=\exp \left[-2.187+0.916^{*} \ln \left(\mathrm{pD}^{2} \mathrm{H}\right)\right]$ \\
Urquiza-Haas et al., 2007 & 0.902 & $\mathrm{AGB}=\exp \left\{2.12605+0.868 \ln \left(\mathrm{D}^{2} \mathrm{H}\right)\right.$ \\
Guyot and Proust, unpublished data & 0.843 & $\ln (\mathrm{AGB})=1.3636^{*} \ln (\mathrm{D})+1.615 \mathrm{O}^{*} \ln (\mathrm{H})-2.9267$ \\
\hline AGB is the total dry weight $(\mathrm{kg})$, D is the diameter at breast height $(\mathrm{cm})$, His the height $(\mathrm{m})$ and p is the specific weight of the timber $\left(\mathrm{g} \mathrm{cm}^{-3}\right)$
\end{tabular}

AGB is the total dry weight (kg), $D$ is the diameter at breast height $(\mathrm{cm}), H$ is the height $(\mathrm{m})$ and $p$ is the specific weight of the timber $\left(g \mathrm{~cm}^{-3}\right)$.

To obtain total tree biomass we also consider the formula of Mokany and collaborators (2006) for root biomass: RB $=0.489(\mathrm{AGB})^{0.89}$. The total biomass value $(\mathrm{AGB}+\mathrm{RB})$ in kilograms was subsequently extrapolated to tons per hectare $\left(\mathrm{Mg} \mathrm{ha}^{-1}\right)$ and multiplied by 0.47 (carbon factor) in order to obtain the quantity of carbon per hectare $(\mathrm{Mg}$ $\mathrm{ha}^{-1}$ ) of the ACA and per cubic meter of timber harvested $\left(\mathrm{Mg} \mathrm{m}^{-3}\right)$, to assess impacts per volume of roundwood extracted, (i.e., by area and by efficiency, respectively).

A regression analysis was conducted to evaluate the allometric equations (Table 2). While the closest relationship (0.95) to the forestry inventory data was found with Cairns et al. (2003) (Table 2), we opted for Chave and collaborators $(2014)$ with the second-best fit $\left(R^{2}=0.93\right)$ to facilitate global comparisons, since it includes a bioclimatic variable $(\mathrm{E})$ which is a function of climate water deficit, temperature seasonality and precipitation seasonality.

\section{RESULTS}

A total of 815 stumps were georeferenced in the ACAs of both ejidos, of which 418 were sampled to measure extracted timber and collateral damage. In addition, 41.3 $\mathrm{km}$ of skid trails and $5.2 \mathrm{~km}$ of haul roads were measured and sampled (Table 3) within the two ACAs. The most commonly felled species were tzalam (Lysiloma latisiliquum (L.) Benth: $31 \%$ of the total) and caoba (S. macrophylla: $28 \%$ ) in the Caobas ejido, and machiche (Lonchocarpus castilloi Standl.: 32\%), pucté (Bucida buceras L.: 25\%) and zapote ( $M$. zapota: $20 \%$ ) in the 20 de Noviembre ejido. A total of $46 \%$ of the felled trees presented dbh values of between $46 \mathrm{~cm}$ and $63 \mathrm{~cm}$ and the rest (54\%) were smaller diameter timber
( $35 \mathrm{~cm}$ to $45 \mathrm{~cm} \mathrm{dbh).} \mathrm{The} \mathrm{main} \mathrm{types} \mathrm{of} \mathrm{collateral} \mathrm{damage}$ during felling were $S$ and $G$ in both ejidos, and from skidding, $G$ trees in the 20 de Noviembre ejido, and $S$ and $G$ in the Caobas ejido (Fig. 2).

\section{Carbon emissions}

Using the allometric equation of Chave and collaborators (2014), it was estimated that the impact on forest vegetation generated by selective logging in the studied ejidos produces an average of $1.32 \mathrm{Mg} \mathrm{ha-1}$ year- $^{-1}$ of carbon emissions. This value was $1.61 \mathrm{Mg} \mathrm{ha}^{-1}$ in the Caobas ejido and $1.05 \mathrm{Mg} \mathrm{ha}^{-1}$ in the 20 de Noviembre ejido (Table 4), despite much higher harvest yields in the former (see Table 3). However, use of a unit of measurement per hectare can be problematic due to the fact that this shows the quantity of carbon extracted per unit area of the ACA, rather than by the volume harvested in the ACA. For this purpose, we used the measurement of carbon emissions per cubic meters of timber extracted $\left(\mathrm{m}^{3}\right)$ in order to analyze and compare the efficiency of harvest activities in minimizing carbon emissions. These results were $1.2 \mathrm{Mg} \mathrm{m}^{-3}$ in the Caobas ejido and $1.5 \mathrm{Mg} \mathrm{m}^{-3}$ in the 20 de Noviembre ejido, considering that the first extracted twice the volume of wood. Of the total emissions, $65 \%$ come from felled tree remainders and the extracted tree, although of this proportion, less than $7 \%$ of carbon impacts come from roundwood extracted from the site. The second greatest source of emissions come from skidding operations (around 11\%) and carbon impacts from timber transport activities (i.e. construction of log landings and haul roads) 
TABLE 3. Summary of the sampling conducted in two ejidos in the southern Yucatán peninsula, Mexico.

\begin{tabular}{|c|c|c|c|}
\hline Activity & & Ejido Caobas & Ejido 20 de Nov \\
\hline Felling area (ha) & & 847.2 & 1000 \\
\hline Volume extrated $\left(\mathrm{m}^{3}\right)$ & & 1605 & 685.7 \\
\hline Biomass (Mg ha-1) & & 76.6 & 51.9 \\
\hline \multirow{3}{*}{ Felling (No.) } & Trees felled and quantified & 467 & 348 \\
\hline & Trees felled and measured & 70 & 320 \\
\hline & $\begin{array}{l}\text { Average number of trees damaged } \\
\text { per individual felling event }\end{array}$ & 3.2 & 6.5 \\
\hline \multirow{3}{*}{ Skidding } & Average skid trail width (m) & 3.0 & 3.2 \\
\hline & Total skid trail length (km) & 6.9 & 12.9 \\
\hline & Skid trail plots (No.) & 21 & 95 \\
\hline \multirow{3}{*}{ Transport } & Average road width (m) & 4.3 & 5.5 \\
\hline & Total road length (km) & 3.1 & 2.1 \\
\hline & $\begin{array}{l}\text { Number and area of the log } \\
\text { landings }\left(\mathrm{m}^{2}\right)\end{array}$ & $9(10745)$ & 7 (3362) \\
\hline
\end{tabular}

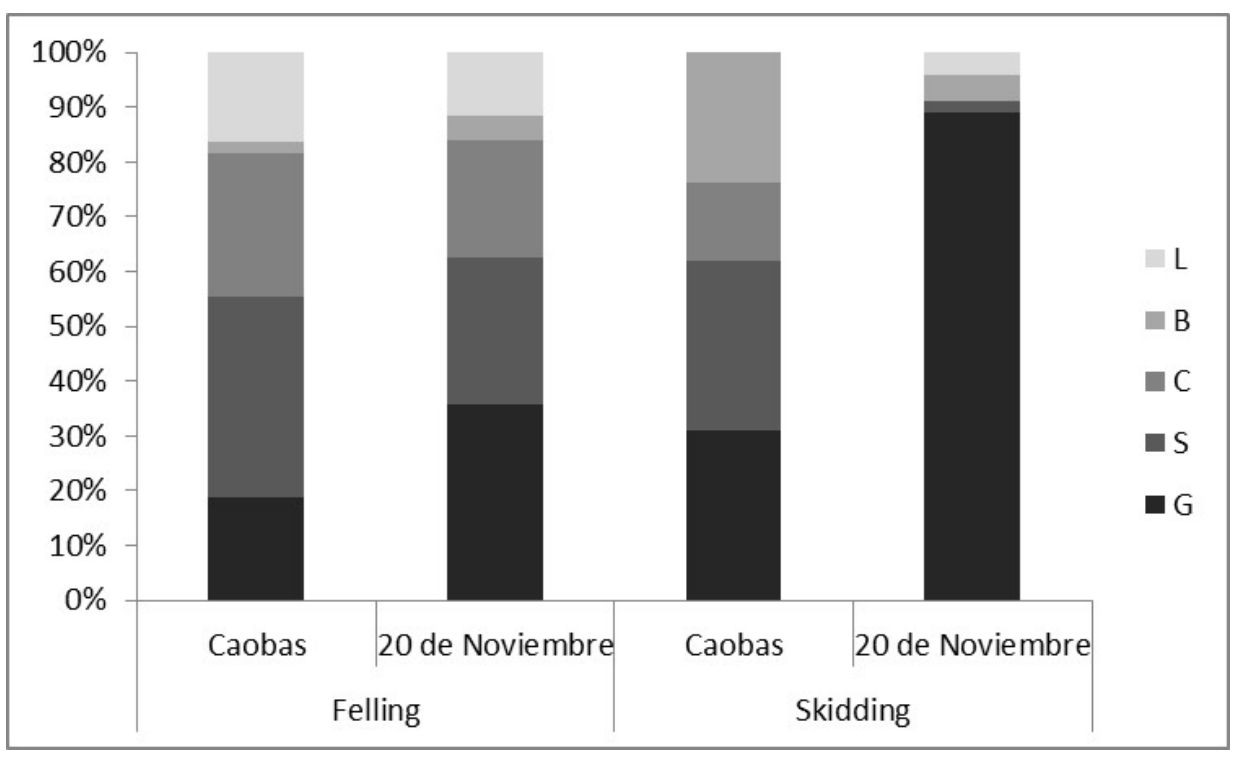

FIGURE. 2. Types of collateral damage through felling and the opening of skid trails in the ejidos Caobas and 20 de Noviembre of the Yucatán Peninsula, Mexico.

G, totally fallen; S, broken; C, decrowned; B, bark stripped; L, leaning $\geq 10^{\circ}$ 
TABLE 4. Estimation of carbon emissions from selective logging in the ejidos Caobas and 20 de Noviembre, in the southern Yucatán Peninsula, Mexico.

\begin{tabular}{|c|c|c|c|c|c|c|}
\hline & \multicolumn{3}{|c|}{ Ejido Caobas } & \multicolumn{3}{|c|}{ Ejido 20 de Noviembre } \\
\hline & $\mathrm{Mg} \mathrm{ha}^{-1}$ & $M g m^{-3}$ & $\%$ & $\mathrm{Mg} \mathrm{ha}^{-1}$ & $\mathrm{Mg} \mathrm{m}^{-3}$ & $\%$ \\
\hline Haul road $(\mathrm{T})$ & 0.04 & 0.03 & 2 & 0.06 & 0.08 & 5 \\
\hline Log landings (T) & 0.10 & 0.07 & 6 & 0.02 & 0.03 & 2 \\
\hline Skid trails (S) & 0.18 & 0.13 & 11 & 0.12 & 0.18 & 12 \\
\hline Felled tree remainder $(\mathrm{F})$ & 1.07 & 0.80 & 67 & 0.67 & 0.98 & 64 \\
\hline Felling damage (F) & 0.07 & 0.05 & 5 & 0.13 & 0.18 & 12 \\
\hline Harvest timber (F) & 0.15 & 0.11 & 9 & 0.05 & 0.08 & 5 \\
\hline Total & 1.61 & 1.19 & 100 & 1.05 & 1.53 & 100 \\
\hline
\end{tabular}

were the lowest source $(<8 \%)$. There are important differences between the two studied ejidos in terms of collateral damage caused during felling, which accounts for $5 \%$ and $12 \%$ of the total emissions in Caobas and 20 de Noviembre ejidos, respectively. This is in addition to the opening of haul roads (Table 4).

\section{DISCUSSION}

\section{Carbon emissions as a result of forestry activity}

This study quantified committed carbon emissions from selective logging in the southern Yucatan Peninsula. Carbon impacts per intervened area are $1.61 \mathrm{Mg} \mathrm{ha}^{-1}$ and $1.05 \mathrm{Mg} \mathrm{ha}^{-1}$ for the Caobas and 20 de Noviembre ejidos, respectively. These values are far below results obtained for Indonesia in Dipterocarpaceae forest using the same methodology by Griscom et al. (2014), which was $51.1 \mathrm{Mg}$ $\mathrm{ha}^{-1}$ of carbon. Moreover, the average number of damaged trees per felling event in the southern Yucatan Peninsula (5) is considerably less than the 10-20 trees damaged per felled tree reported for logging in other countries of the tropics (Putz et al., 2008b).

Results of the committed carbon emissions per cubic meter $\left(\mathrm{Mg} \mathrm{m}^{-3}\right)$ of harvested timber show clear differences between the two ejidos. Even though three times more trees were harvested in the Caobas ejido than in the 20 de Noviembre ejido, the collateral damage per volume extracted caused by felling and opening of skid trails is greater in the latter (Table 3). Collateral damage per harvested volume from felling operations was much lower in Caobas, thanks in part to directional felling, an activity classified as a RIL practice (Putz et al., 2008a), showing only $0.05 \mathrm{Mg} \mathrm{m}^{-3}$ of resulting emissions of carbon compared to $0.18 \mathrm{Mg} \mathrm{m}^{-3}$ due to the felling in the 20 de Noviembre ejido. Furthermore, in Caobas, the lianas and vines are cut just before felling, which prevents the entanglements that can cause the loss of neighboring trees. This is another RIL practice (Putz et al., 2008a) and is also recommended for the safety of the ejido brigades that conduct selective logging.

In the case of the skid trails, we found a value of 0.13 $\mathrm{Mg} \mathrm{m}^{-3}$ of carbon in the Caobas ejido compared to $0.18 \mathrm{Mg}$ $\mathrm{m}^{-3}$ in the 20 de Noviembre ejido. These differences could be due in part to the type of machinery used and the way the skid trails are opened. In Caobas, logs are mainly skidded with a modified agricultural tractor (Table 1), necessitating the manual cutting of only smaller trees to cut a path that allow the tractor to skid logs. Smaller width and weight of the modified tractor notably causes less forest biomass impacts than a conventional skidder (locally known as Tree Farmer) which was used by 20 de Noviembre for all skidding operations. Skidding with a Tree Farmer allows straight-line advances through the forest, crushing all of the trees in the skid trail. This type of 
vehicle also explains why the most common type of damage observed in the 20 de Noviembre ejido is totally fallen $(\mathrm{G})$.

With respect to opening of haul roads, the Caobas ejido uses old roads that were opened more than thirty years ago while forestry operations in the 20 de Noviembre ejido regularly opens new roads, increasing the quantity and size of damaged trees and thus the amount of carbon impacts. Regarding this activity, it is important to mention that both ejidos plan roads and skid trails prior to harvesting. This is one of the main RIL practices recommended in order to minimize forest impacts from selective logging. However, the use of alternative skidding or hauling technology, such as a modified agricultural tractor also shows more promise as an additional method to substantially reduce carbon emissions from skidding timber. Ellis et al. (2019) found that the use of modified agricultural tractors for skidding reduced carbon emissions by $0.15 \mathrm{Mg} \mathrm{m}^{-3}$ or $5 \mathrm{Mg} \mathrm{km}^{-1}$ of skidstrail in forestry ejidos of the region.

Comparing our data with those of other countries, we found that ejido Caobas presents one of the lowest carbon emission rates per cubic meter of timber extracted, $1.19 \mathrm{Mg} \mathrm{m}^{-3}$ (Table 5). According to Pearson, Brown and Casarim (2014) and Griscom et al. (2014), all the studies conducted so far correspond to timber company concessions who are in charge of logging and harvest much larger timber volumes. This contrasts with our study, in which both ejidos conduct selective logging through community forestry management. It is also important to note that the other countries studied typically employ heavy machinery (bulldozers) and, on most occasions, take no measures to protect trees of less than 50 cm of dbh (Pearson et al., 2014).

\section{Forestry certification}

Forestry certification aims to maintain the integrity of forestry ecosystems (Kalonga, Midtgaard \& Klanderud, 2016) through recognition and certification of responsible practices in forest management (Romero et al., 2015). At present, there is some controversy regarding the effectiveness of forestry certification in terms of fulfilling its main objective (Romero et al., 2015; Burivalova et al., 2016; Kalonga et al., 2016). Since 2013, the Caobas ejido has had the certification seal of the FSC, assigned by Rainforest Alliance. This certification requires the annual analysis of all relevant documents, permits, and forestry reports of the ejido, combined with field surveys. Certification is only reauthorized when the ten principles of the FSC are found to have been met (FSC, 2010).

TABLE 5. Carbon emissions per cubic meter $\left(\mathrm{Mg} \mathrm{m}^{-3}\right)$ in different countries that practice selective logging.

\begin{tabular}{|c|c|c|c|c|}
\hline Country & Region & $M g m^{-3}$ & $M g h a^{-l}$ & Publication \\
\hline Guyana & Upper Demerara/Berbice & 2.3 & 30.3 & Pearson et al. (2014) \\
\hline Mexico & Campeche (20 de Noviembre) & 1.53 & 1.05 & Present study \\
\hline Indonesia & East Kalimantan & 1.4 & 51.1 & Griscom et al. (2013) \\
\hline Mexico & Quintana Roo (Caobas) & 1.19 & 1.61 & Present study \\
\hline Republic of Congo & Sangha & 1.0 & 8.9 & Pearson et al. (2014) \\
\hline
\end{tabular}


For the last two years, ejido Caobas has marked the extracted trees, cut lianas and vines prior to felling, practiced directional felling and, starting in 2016, has also georeferenced trees for extraction and the planning of skid trails. In 20 de Noviembre, directional felling has been tried in some years, but this activity is still not a consolidated practice within the ejido. However, directional felling can help explain the large differences in collateral damage from felling observed between these ejidos, (5\% of emissions in the Caobas ejido compared to $12 \%$ in the 20 de Noviembre ejido).

From this study, it is apparent that certification and RIL practices by community forest management in the southeastern Yucatán Peninsula appear to help reduce the impact of timber harvesting on carbon emissions. Another notable ejido in the same region is Nohbec, which is certified by the FSC and also incorporates RIL practices, including skid trail planning and directional felling (Rainforest Alliance, 2004). Forestry certification has also been reported to be associated with social and environmental benefits (Burivalova et al., 2016). Our findings support previous studies showing that RIL practices are associated with reduced forest disturbance from harvesting (Ellis et al., 2019).

\section{CONCLUSIONS}

The impact of selective logging on estimated carbon emission rates in the southern Yucatán Peninsula is low compared to other regions of the world. The lowest rates were observed for the Caobas ejido, with a long history of community forestry management, implementation of forestry practices that are classified as reduced impact logging (RIL), and FSC certification. Forestry certification appears to fulfill its main objective in Caobas, which is to maintain the integrated and sustainable management of their forests. The 20 de Noviembre ejido provides an example of the efforts that are being made in the region to improve and attain greater efficiency in forestry management, although in reality RIL practices are implemented in relatively few ejidos of the region and forest certification is very difficult to attain for most forestry ejidos (Ellis et al. 2019) . The implementation of RIL practices, such as the use of agricultural tractors, directional felling, planning of skid trails, and the geopositioning of felled trees can all contribute to the certification, however there are also economic and environmental benefits to implementing RIL by community forest management in the region.

RIL practices and community forest management in selectively logged areas on the Yucatan Peninsula can contribute to maintaining carbon stocks and also minimizing carbon emissions in this important forest and biodiverse region. These actions should therefore be considered and integrated into guidelines for the implementation of carbon markets on the part of REDD+ and Conafor in Mexico. Only recently, have organizations such as TNC have begun to promote and finance support for the implementation of RIL-C practices by forestry ejidos on the Yucatan Peninsula; the "C" implying logging practices that have a clear impact on reducing carbon emissions (Ellis et al. 2019).

\section{ACKNOWLEDGEMENTS}

We acknowledge the facilities provided by the people of the Ejido Caobas and 20 de Noviembre. We also thank Irving U. Hernández Gómez for support in field. We acknowledge the support of the Consejo Nacional de Ciencia y Tecnología (Conacyt) to SAM via the scholarship No. 272614. Funding for this research was made possible by the United States Agency for International Development (USAID), under the terms of the Cooperation Agreement No. AID-523-A-11-00001 (Proyecto de Reducción de Emisiones por la Deforestación y la Degradación de Bosques de México) implemented by the main awardee The Nature Conservancy (TNC) and its partners (Rainforest Alliance, Woods Hole Research Center and Espacios Naturales y Desarrollo Sustentable).

\section{REFERENCES}

Abdullahi, A. C., Siwar, C., Shaharudin, M. I. I., \& Anizan, I. (2018). The effects of forest type and land use on soil carbon stock in 
Malaysian dipterocarps forests. Advanced and Applied Sciences, 5(8), 11-17. doi: $10.21833 /$ ijaas.2018.08.002

Angelsen, A., Brown, S., Loisel, C., Peskett, L., Streck, C., \& Zarin, D. (2009). Reducing emissions from deforestation and forest degradation (REDD): an options assessment report. Washington: Meridian Institute.

Asner, G. P., Rudel, T. K., Aide, T. M., Defries, R., \& Emerson, R. (2009). A contemporary assessment of change in humid tropical forests. Conservation Biology, 23, 1386-1395. doi: 10.1111/j.15231739.2009.01333.x.

Borrego, A. \& Skutsch, M. (2014). Estimating the opportunity costs of activities that cause degradation in tropical dry forest: Implications for REDD+. Ecological Economics, 101, 1-9. doi: $\underline{10.1016 / \text { i.ecolecon.2014.02.005 }}$

Bryan, J., Shearman, P., Ash, J., Kirkpatrick, J. B. (2010). Estimating rainforest biomass stocks and carbon loss from deforestation and degradation in Papua New Guinea 1972-2002: Best estimates, uncertainties and research needs. Journal Environmental Management, 91(4), 995-1001. doi: 10.1016/j.jenvman.2009.12.006.

Burivalova, Z., Hua, F., Koh, L. P., Garcia, C., \& Putz, F. E. (2016). A critical comparison of conventional, certified, and community management of tropical forests for timber in terms of environmental, economic, and social variables. Conservation Letters, 10, 4-14. doi: $10.1111 /$ conl.12244

Burns, S. L., Yapura, P. F., \& Giessen, L. (2016). State actors and international forest certification policy: Coalitions behind FSC and PEFC in federal Argentina. Land Use Policy, 52, 23-29. doi: $\underline{10.1016 / \text { i.landusepol.2015.12.005 }}$

Cairns, M.A., Olmsted, I., Granados, J., \& Argaez, J. (2003). Composition and aboveground tree biomass of a dry semievergreen forest on Mexico's Yucatan Peninsula. Forest Ecology and Management, $\quad 186(1-3), \quad 125-132 . \quad$ doi: 10.1016/S03781127(03)00229-9

Chave, J., Andalo, C., Brown, S., Cairns, M. A., Chambers, J. Q., Eamus, D., .. \& Yakamura, T. (2005). Tree allometry and improved estimation of carbon stocks and balance in tropical forests. Oecologia, 145, 87-99. doi: 10.1007/s00442-005-0100-x

Chave, J., Réjou-Méchain, M., Búrquez, A., Chidumayo, E., Colgan, M. S., Delitti, W. B. C., ... \& Vieilledent, G. (2014). Improved allometric models to estimate the aboveground biomass of tropical trees. Global Change Biology, 20, 3177-3190. doi: $\underline{10.1111 / g c b .12629}$

Comisión Nacional Forestal [Conafor] (2015). Proyecto Fortalecimiento REDD+ y Cooperación Sur-Sur. Retrieved from www.mrv.mx.
Cronkleton, P., Bray, D. B., \& Medina, G. (2011). Community forest management and the emergence of multi-scale governance institutions: Lessons for REDD+ development from Mexico, Brazil and Bolivia. Forests, 2, 451-473. doi: $\underline{10.3390 / £ 2020451}$

Denman, K. L., Brasseur, G., Chidtaisong, A., Ciais, P., Cox, P. M., Dickinson, R. E., ... \& Zhang, X. (2007). Couplings between changes in the climate system and biochemistry. In S. Solomon, D. Qin, M. Manning, Z. Chen, M. Marquis, K. B. Averty, ... \& H. L. Miller (Eds.), Climate change 2007: The physical science basis. Contribution of working group I to the fourth assessment report of the intergovernmental panel on Climate change (p. 499-587). Cambridge and New York: Cambridge University Press.

Ellis, E. A., Armenta-Montero, S., Hernández-Gómez, I. U., RomeroMontero, J. A., Ellis, P. W., Rodríguez-Ward, D., Blanco-Reyes, P., \& Putz, F. E. (2019). Reduced-impact logging practices reduce forest disturbance and carbon emissions in community managed forests on the Yucatán Peninsula, Mexico. Forest Ecology and Management, 437, 396-10. doi: 10.1016/j. foreco.2019.01.040

Ellis, E. A., Kainer, K. A., Sierra-Huelsz, J. A., Negreros-Castillo, P., Rodríguez-Ward, D., \& DiGiano, M. (2015). Endurance and adaptation of community forest management in Quintana Roo, Mexico. Forests, 6, 4295-4327. doi: 10.3390/f6114295

Food and Agriculture Organization [FAO] 2015. Global Forest Resource Assessment 2015: How are the World's Forest Changing? FAO, Rome, Italy. Retrieved from http://www.fao.org/3/a-i4793e.pdf

Fahey, T. J., Woodbury, P. B., Battles, J. J., Goodale, C. L., Hamburg, S. P., Ollinger, S. V., \& Woodall, C. W. (2009). Forest carbon storage: ecology, management, and policy. Frontiers in Ecology and the Environment, 8(5), 245-252. doi: 10.1890/080169

Forest Stewardship Council [FSC] (2010). Estándares mexicanos para la certificación del manejo forestal FSC. FSC, D.F. Retrieved from https://mx.fsc.org/preview.fsc-std-mex-05-2010-mexiconatural-and-plantation-es.a-62.pdf

Foundation for International Environmental Law and Development [FIELD] (2013). Guía para los negociadores de REDD-plusVersión 2013. Retrieved from http:/ / reddcr.go.cr/sites/default/files/centro-dedocumentacion/gui_a_para_los_negociadores_de_redd_field.pd f

Federici, S., Tubiello, F. N., Salvatore, M., Jacobs, H., \& Schmidhuber, J. (2015). New estimates of CO2 forest emissions and removals: 1990-2015. Forest Ecology and Management, 352, 89-98. doi: 10.1016/i.foreco.2015.04.022

Gil-González, I. J. \& Prada-Garzón, R. G. (2008). Análisis y caracterización de las propiedades físicas y mecánicas de la palma de lata (Bachelor thesis). Universidad Industrial de Santander, Bucaramanga, Colombia. 
Retrieved

from https://studylib.es/doc/4595045/an\%C3\%A1lisis-ycaracterizaci $\% \mathrm{C} 3 \% \mathrm{~B} 3 \mathrm{n}$-de-las-propiedades-f $\% \mathrm{C} 3 \% \mathrm{AD}$ sicas-y-m.

González, A., Schmook, B., \& Calmé, S. (2007). Distribución espaciotemporal de las actividades extractivas en los bosques del ejido Caoba, Quintana Roo. Investigaciones Geográficas, 62, 69-86.

Griscom, B., Ellis, P., \& Putz, F. (2014). Carbon emissions performance of commercial logging in East Kalimantan, Indonesia. Global Change Biology, 20, 923-937. doi: 10.1111/gcb.12386

Griscom, B., Ganz, D., Virgilio, N., Price, F., Hayward, J., Cortez, R., ... \& Stanley, B. (2009). The bidden frontier of forest degradation: a review of the science, policy and practice of reducing degradation emissions. Retrieved from

https://www.conservationgateway.org/Documents/The $\% 20 \mathrm{Hi}$ dden $\% 20$ Frontier $\% 20$ of $\% 20$ Forest $\% 20$ Degradation.pdf.

Halperin, J. J. \& Turner, R. L. (2013). Forest degradation in Cambodia: an assessment of monitoring options in the Central Cardamom Protected Forest. Retrieved from http://www.leafasia.org/sites/default/files/public/resources/d egradation-cambodia-report-final.pdf.

Instituto Nacional de Ecología y Cambio Climático [INECC] (2012). México Quinta Comunicación Nacional ante la Convención Marco de las Naciones Unidas sobre el Cambio Climático. Retrieved from https://unfccc.int/resource/docs/natc/mexnc5s.pdf

Instituto Nacional de Estadística y Geografía [Inegi] (2016). Censo Agropecuario 2007, IX Censo Ejidal. Retrieved from http://www.beta.inegi.org.mx/proyectos/encagro/ena/2017/

Intergovernmental Panel on Climate Change [IPCC] (2014). Cambio climático 2014: Informe de sintesis. Contribución de los Grupos de trabajo I, II y III al Quinto Informe de Evaluación del Grupo Intergubernamental de Expertos sobre el Cambio Climático [Equipo principal de redacción, R.K. Pachauri y L.A. Meyer (eds.)]. IPCC, Ginebra, Suiza, 157 p.

Intergovernmental Panel on Climate Change [IPCC] (2015). Climate Change 2014: Mitigation of Climate Change. In O. Edenhofer, R. Pichs-Madruga, Y. Sokona, E. Farahani, S. Kadner, K. Seyboth, ... \& J.C. Minx (Eds.), Contribution of Working Group III to the Fifth Assessment Report of the Intergovernmental Panel on Climate Change. Cambridge and New York: Cambridge University Press.

International Tropical Timber Organization [ITTO] (2012). Caracterización tecnológica de las especies de Madera. Retrieved from http://www.itto.int/files/itto_project_db_input/2596/Technic al/Capitulo\%203\%20Caracterizacion $\% 20$ tecnol $\%$ C3\%B3gica $\%$ $20 \mathrm{de} \% 20 \mathrm{las} \% 20$ especies $\% 20 \mathrm{de} \% 20$ madera.pdf.

Kalonga, S. K., Midtgaard, F., \& Klanderud K. (2016). Forest certification as a policy option in conserving biodiversity: An empirical study of forest management in Tanzania. Forest Ecology and Management, 361, 1-12. doi: 10.1016/j.foreco.2015.10.034

Kindermann, G., Obersteiner, M., Sohngen, B., Sathaye, J., Andrasko, K., Rametsteiner E, ... \& Beach, R. (2008). Global cost estimates of reducing carbon emissions through avoided deforestation. Proceedings of the National Academy of Sciences of the United States of America, 105(30), 10302-10307. doi: 10.1073/pnas.0710616105

Martin, P. A., Newton, A. C., Pfeifer, M., Khoo, M., \& Bullock, J. M. (2015). Impacts of tropical selective logging on carbon storage and tree species richness: A meta-analysis. Forest Ecology and Management, 356, 224-233. doi: 10.1016/j.foreco.2015.07.010

Masera, O., Ordoñez, M., \& Dirzo, R. (1997). Carbon emissions from Mexican forests: current situation and long-term scenarios. Climatic Change, 35(3), 265-295. doi: 10.1023/A:1005309908420

Mazzei, L., Sist, P., Ruschel, A., Putz, F. E., Marco, P., Pena, W., \& Ferreira, J. E. R. (2010). Above-ground biomass dynamics after reduced-impact logging in the Eastern Amazon. Forest Ecology and Management, 259(3), 367-373. doi: 10.1016/i.foreco.2009.10.031

Mokany, K., Raison, R. J., \& Prokushkin, A. S. (2006). Critical analysis of root: shoot ratios in terrestrial biomes. Global Change Biology, 12, 84-96. doi: 10.1111/j.1365-2486.2005.001043.x

Morales-Barquero, L., Skutsch, M., Jardel-Peláez, E. J., Ghilardi, A., Kleinn, C., \& Healey, J. R. (2014). Operationalizing the definition of forest degradation for REDD+, with application to Mexico. Forests, 5(7), 1653-1681. doi: 10.3390/f5071653

Murdiyarso, D., Skutsch, M., Guariguata, M., Kanninen, M., Luttrell, C., Verweij, P., \& Stella-Martins, O. (2008). ¿Cómo medimos y monitoreamos la degradación forestal? In A. Angelsen (Ed.), Avancemos con REDD: problemas, opciones y consecuencias (pp. 99-106). Bogor: CIFOR.

Navarro-Martínez, A., Palmas, S., Ellis, E. A., Blanco-Reyes, P., VargasGodínez, C., Iuit-Jiménez, A. C., ... \& Putz, F. E. (2017). Remnant Trees in Enrichment Planted Gaps in Quintana Roo, Mexico: Reasons for Retention and Effects on Seedlings. Forests, 8(8), 1-11. doi: $10.3390 /$ f8080272

Pearson, T. R., Brown, S., \& Casarim, F. M. (2014). Carbon emissions from tropical forest degradation caused by logging. Environmental Research Letters, 9(3), $034017 . \quad$ doi: 10.1088/17489326/9/3/034017

Pearson, T. R., Brown, S., Murray, L., \& Sidman, G. (2017). Greenhouse gas emissions from tropical forest degradation: an underestimated source. Carbon balance and management, 12(1), 3. ‥ $\underline{10.1186 / s 13021-017-0072-2}$ 
Pinard, M. A., Putz, F. E., \& Tay, J. (2000). Lessons learned from the implementation of reduced-impact logging in hilly terrain in Sabah, Malaysia. The International Forestry Review, 2(1), 33-39.

Porter-Bolland, L., Ellis, E. A., Guariguata, M. R., Ruiz-Mallén, I., Negrete-Yankelevich, S., \& Reyes-García, V. (2012). Community managed forests and forest protected areas: An assessment of their conservation effectiveness across the tropics. Forest Ecology and Management, 268, 6-17. doi: 10.1016/i.foreco.2011.05.034

Putz, F. E. \& Redford, K. H. (2010). The importance of defining 'forest': tropical forest degradation, deforestation, long-term phase shifts, and further transitions. Biotropica, 42, 10-20. doi: 10.1111/j.17447429.2009.00567.x.

Putz, F. E., Sist, P., Fredericksen, T., \& Dykstra, D. (2008a). Reducedimpact logging: Challenges and opportunities. Forest Ecology and Management, 256, 1427-1433. doi: 10.1016/i.foreco.2008.03.036

Putz, F. E., Zuidema, P. A., Pinard, M. A., Boot, R. G. A., Sayer, J. A., Sheil, D., ... \& Vanclay, J. K. (2008b). Improved tropical forest management for carbon retention. PLoS Biol, 6(7), e166. doi: 10.1371/journal.pbio.0060166

Putz, F. E., Zuidema, P. A., Synnott, T., Peña-Claros, M., Pinard, M. A., Sheil, D., ... \& Zagt, R. (2012). Sustaining conservation values in selectively logged tropical forests: the attained and the attainable. Conservation Letters, 5, 296-303. doi: 10.1111/j.1755263X.2012.00242.X

Rainforest Alliance. (2004). Resumen Público de Certificación de Ejido Nob Bec. New York. Retrieved from https://www.rainforestalliance.org/business/forestry/documents/noh_bec.pdf.

Romero, C., Putz, F. E., Guariguata, M. R., Sills, E. O., Cerutti, P. O., \& Lescuyer, G. (2013). An overview of current knowledge about the impacts of forest management certification: A proposed framework for its evaluation. Bogor: CIFOR.

Romero, C., Putz, F. E., Guariguata, M. R., Sills, E. O., Maryudi, A., \& Ruslandi. (2015). The context of natural forest management and FSC certification in Indonesia. CIFOR, Bogor. Retrieved from http:/ / www.cifor.org/publications/pdf_files/OccPapers/OP-126.pdf

Sasaki, N. \& Putz, F. E. (2009). Critical need for new definitions of "forest" and "forest degradation" in global climate change agreements. Conservation Letters, 2, 226-232. doi: 10.1111/j.1755263X.2009.00067.X

Scharlemann, J. P. W., Tanner, E. V. J., Hiederer, R., Kapos, V. (2014). Global soil carbon: understanding and managing the largest terrestrial carbon pool. Carbon Management, 5(1), 81-91. doi: $10.4155 / \mathrm{cmt} .13 .77$

Simula, M. \& Mansur, E. (2011). Un desafío mundial que reclama una respuesta local. Unasylva, 62(238), 3-7.
Sociedad de Productores Forestales Ejidales de Quintana Roo S. C. [SPFEQRSC] (2012). Programa de Manejo Forestal Permanente Ejido Caoba, municipio de Othón P. Blanco. Segundo ciclo de corta. 63. Chetumal: Sociedad de Productores Forestales Ejidales de Quintana Roo S. C.

Thompson, I. D., Guariguata, M. R., Okabe, K., Bahamondez, C., Nasi, R., Heymell, V., \& Sabogal, C. (2013). An operational framework for defining and monitoring forest degradation. Ecology and Society, 18(2), 20.

Urquiza-Haas, T., Dolman, P. M., \& Peres, C. A. (2007). Regional scale variation in forest structure and biomass in the Yucatan Peninsula, Mexico: Effects of forest disturbance. Forest Ecology and Management, 247, 80-90. doi: 10.1016/j.foreco.2007.04.015

Vanguelova, E., Pitman, R., Luiro, J., \& Helmisaari, H. S. (2010). Long term effects of whole tree harvesting on soil carbon and nutrient sustainability in the UK. Biogeochemistry, 101(1-3), 43-59. doi: 10.1007/s10533-010-9511-9

Walker, S. M., Pearson, T. R. H., Casarim, F. M., Harris, N., Petrova, S., Grais, A., ... \& Brown, S. (2012). Standard Operating Procedures for Terrestrial Carbon Measurement. Retrieved from https://www.winrock.org/wpcontent/uploads/2016/03/Winrock_Terrestrial_Carbon_Field_ SOP_Manual_2012_Version.pdf

West, T. A. P., Vidal, E., \& Putz, F. E. (2014). Forest biomass recovery after conventional and reduced-impact logging in Amazonian Brazil. Forest Ecology and Management, 314, 59-63. doi: $\underline{10.1016 / \text { i.foreco.2013.11.022 }}$

Zhang, X., Guan, D., Li, W., Sun, D., Jin, C., Yuan, F., ... \& Wu, J. (2018). The effects of forest thinning on soil carbon stocks and dynamics: A meta-analysis. Forest Ecology and Management, 429, 3643. doi: $10.1016 /$ i.foreco.2018.06.027.

\section{Received: 29 November 2018}

Accepted: 23 May 2019

Published: 27 February 2020

This paper must be cited as:

Armenta-Montero, S., Ellis, E. A., Ellis, P. W., Manson, R. H., López-Binnqüist, C., \& Villaseñor P., J. A. (2020). Carbon emissions from selective logging in the southern Yucatan Peninsula, Mexico. Madera y Bosques, 26(1), e2611891

Madera y Bosques by Instituto de Ecología, A.C. is distributed under a Creative Commons Licence Attribution-NonCommercial-ShareAlike $\quad 4.0$ Internacional. 